\title{
Review
}

\section{The power of memory in democratic politics}

\author{
P.J. Brendese \\ University of Rochester Press, New York, 2014, 234 pp., \$85/£55, \\ ISBN-13: 978-1580464239
}

Contemporary Political Theory (2017) 16, 141-143. doi:10.1057/cpt.2015.56; advance online publication 19 January 2016

Liberal social contract theorists have long argued that political societies ought to jettison public memories of inexpiable historical wrongs, such that serious disagreements can be forgotten and social cohesion reinforced. Thomas Hobbes notoriously argued that such a society, structured around mutual absolution, requires that 'men forget'. The idea that irrevocable differences need to be sublimated, and that this can be achieved through collective amnesia, was also espoused by John Rawls, who argued that justice can only be imagined from the perspective of one who forgets who one is, such that the world can be objectively envisioned through a 'veil of ignorance'.

In his recent book, The Power of Memory in Democratic Politics, P.J. Brendese powerfully unsettles the assumptions that underlie this tradition of thought, and articulates an alternative, more democratic model of responding to the legacies of the past. Through sophisticated new readings of Sophocles, Baldwin, Morrison, Derrida and others, Brendese grapples with the question of what a politics of memory that 'lends itself to democratic possibility' might look like. He also engages with a host of historical sites that illuminate the stakes at play in that question - from South Africa's Truth and Reconciliation Commission, to slavery and segregation in the United States, and Mexico's struggle to come to terms with its history of disappeared persons during the so-called 'Dirty War'. And he turns to a diverse compilation of textual sites as well, from Sophocles' Antigone, which explores remembrance as an 'intergenerational relationship to time', to James Baldwin's 'Liberalism and the Negro', and Toni Morrison's Beloved, both of which disparage collective forgetting, and replace the concept of a 'post-racial' America with a tragic vision of a country haunted by the historical residues of slavery.

Brendese's argument is that a democratic relationship to time calls on us to view the present as entangled by various overlapping temporalities, 'where multiple pasts can be present concurrently' (p. 19). In particular, he takes account of three types of memory that overlap - active memories, which can be recalled at will; virtual memories, which

(c) 2016 Macmillan Publishers Ltd. 1470-8914 Contemporary Political Theory Vol. 16, 1, 141-143 www.palgrave.com/journals 
inform our experience and behavior unconsciously; and haunting memories, which are 'uninvited but not unconscious', and connote eruptions of the past that return in the present like ghosts. The Power of Memory asks what it means to be attuned to these intersectional temporal registers, and sets as its task the effort to foster 'a critical vigilance toward it'.

To his credit, Brendese is careful to note that his argument is not about 'policing public memory' (p. 19). In this sense, he is not interested in establishing regulative ideals or normative standards that coerce collective remembrance. Rather, his objective is to invoke, without foreclosing, questions that explore the power memory wields as a force for vivifying democratic lifeworlds. In particular, writes Brendese, 'I advance a politics of memory that strives to resist the innocence of amnesia, while sustaining affirmation for radical democracy as the possibility of the impossible' (p. 20).

In this sense, for Brendese, democracy is less about enshrining a set of public institutions that distribute goods and ensure equal rights. Rather, democracy is an open-ended struggle, defined by contestation and continual re-creation characterized by collective efforts to establish conditions of greater freedom, public accountability, inclusivity and deliberative interaction. This struggle is also defined by an openness toward the persistent possibility that 'irregularities' will disturb the taken for granted assumptions that underpin what democracy is or can be in the first place. As such, democracy can never be settled within a stable form, but is lived in the 'subtle and complex interplay between political experience and thought' (p. 21). In this sense, Brendese is deeply informed by Sheldon Wolin, for whom democracy invokes 'a project concerned with the political potentialities of ordinary citizens, that is, with the possibilities for becoming political beings through the self-discovery of common concerns and modes of action for realizing them'. For Brendese, without a politics of memory that is 'equipped to acknowledge the presence of others, their suffering, and their stories', there can be no self-discovery of such common concerns (p. 23).

The chapters are sensitive to critiques of collective memory that posit melancholic attachment, grounded in excessive remembrance, as a political problem for those who ought otherwise to seize prospects for transformation in the present. In particular, Brendese tarries with Nietzsche, for whom too much resentment directed at the past paralyzes subjects of memory. But for Brendese, the amnesiac alternative to remembrance risks adopting a willful innocence toward our past, and potentially reduces us to 'living a life unaware of how memory shapes it' (p. 126). What is more, collective forgetfulness threatens to legitimate the status quo, perpetuate inequalities and inhibit more democratic futures. White denial of racial inequality in the United States, for instance, is anchored in a refusal to come to terms with the persistent effects of antebellum slavery.

A more democratic politics of memory, argues Brendese, is one that has to constantly contend with the agonistic tension between 'remembering to forget and remembering that which others cannot be expected to forget' (p. 126). The former refers to the need to move forward by leaving the past behind, such that a new future 
can be made. The latter suggests that, despite this need, democratic societies must memorialize historical injustices, to prevent further marginalization of victims for whom such injustices are unforgettable. Importantly, for Brendese, the struggle to negotiate this tension ought not to be viewed as an indefinite deferral of democratic decisionism. Indeed, he is rightly wary of the trappings associated with the 'inbetween time' such deferral portends. Rather, The Power of Memory favors a vision of democratization conducive to what Martin Luther King, Jr called 'the fierce urgency of now'. Democracy requires modes of remembrance that prompt vital collective political action in ways that responsibly address unjust and asymmetrical relations of power.

What distinguishes The Power of Memory is the supple way that it parses complex, meaningful questions about the democratic politics of time and public memory. Brendese advocates redemption without closure, remembrance without ressentiment and hope without messianism. He masterfully walks this tightrope, without downplaying all the generative friction inherent to these delicate balances. Indeed, he makes the compelling case that democracy fundamentally consists in reckoning with this precarity. Rather than simply argue that forgetting the past dooms us to repeat it, Brendese presents us with an inspired theory of spectral materialism that goes further, by alerting us to the tragic ways that we abandon our democratic ideals when we willfully forget, even if we do this in the name of democracy itself.

Alexander Keller Hirsch

University of Alaska, Fairbanks, AK 99775, USA

ahirsch@alaska.edu 